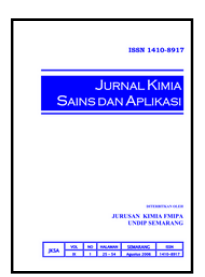

\title{
Pengaruh Penambahan Karboksimetil Selulosa dan Buffer pada Detergensi Surfaktan Hasil Sublasi Limbah Cair Cucian
}

\author{
Diyan Arini ${ }^{a}$, Arnelli ${ }^{a^{*}}$, Ahmad Suseno $^{a}$ \\ a Physical Chemistry Laboratory, Chemistry Department, Faculty of Sciences and Mathematics, Diponegoro University, Jalan Prof. \\ Soedarto, Tembalang, Semarang \\ * Corresponding author: arnelli@live.undip.ac.id
}

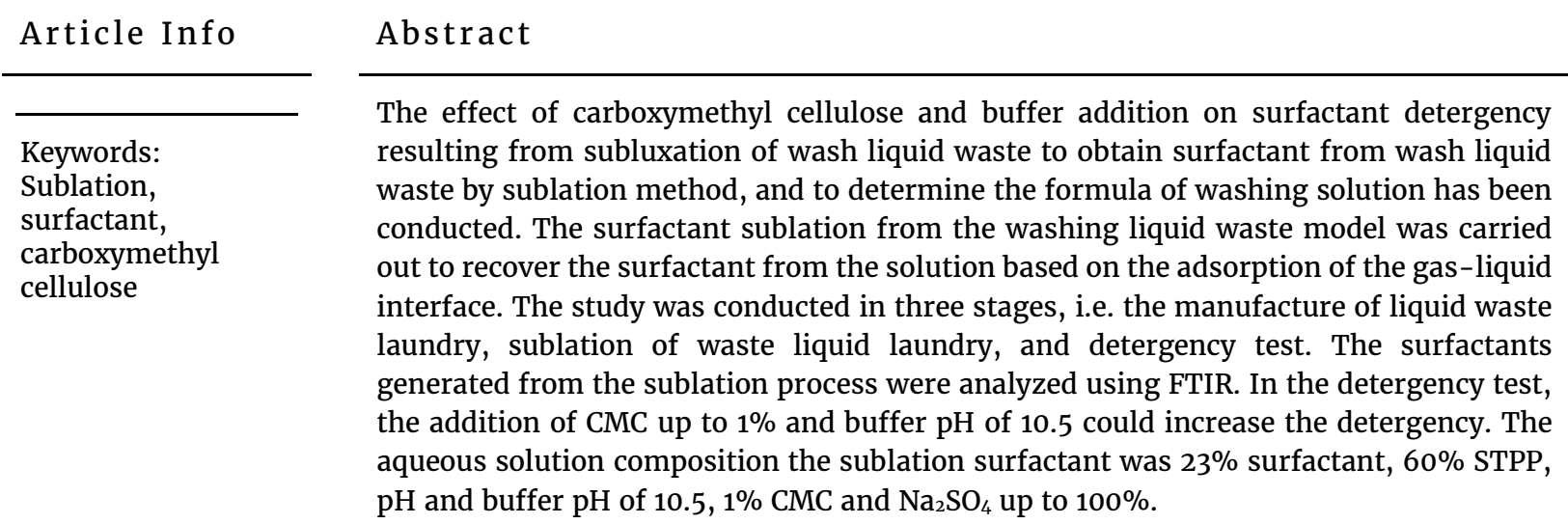

Abstrak

Kata kunci: sublasi, surfaktan, karboksimetil selulosa

Telah dilakukan penelitian pengaruh penambahan karboksimetil selulosa dan buffer pada detergensi surfaktan hasil sublasi limbah cair cucian untuk mendapatkan surfaktan dari limbah cair cucian dengan metode sublasi, serta untuk menentukan formula larutan pencuci. Proses sublasi surfaktan dari model limbah cair cucian dilakukan untuk mengambil kembali surfaktan dari larutannya berdasarkan pada adsorbsi antar muka gas-cair. Penelitian dilakukan dalam tiga tahap, yaitu pembuatan limbah cair cucian, sublasi limbah cair cucian, dan uji detergensi. Surfaktan yang dihasilkan dari proses sublasi dianalisis menggunakan FTIR. Pada uji detergensi, penambahan CMC sampai $1 \%$ dan buffer $\mathrm{pH}$ 10,5 dapat meningkatkan detergensi. Susunan larutan pencuci dari surfaktan hasil sublasi adalah $23 \%$ surfaktan, $60 \%$ STPP, pH dan buffer $\mathrm{pH}$ 10.5, 1\% CMC dan $\mathrm{Na}_{2} \mathrm{SO}_{4}$ sampai $100 \%$.

\section{Pendahuluan}

Perkembangan ilmu pengetahuan dan kemajuan dalam bidang teknologi telah banyak menghasilkan produk industri yang bermanfaat. Detergen merupakan salah satu produk industri yang sangat berguna bagi masyarakat khususnya dalam melindungi kebersihan dan kesehatan tubuh manusia. Namun, penggunaan detergen yang berlebihan dapat menyebabkan pencemaran lingkungan karena detergen yang digunakan dapat terurai dalam jangka waktu 30 tahun.
Indonesia dengan jumlah penduduk 220 juta jiwa atau sekitar 40 juta rumah tangga, bila diasumsikan bahwa setiap rumah tangga menggunakan 50 gram detergen/hari, maka setiap tahunnya sebanyak 720 ribu ton detergen yang akan mencemari lingkungan dan jumlah ini belum termasuk aktifitas industri detergen [1].

Salah satu cara mengatasi permasalahan lingkungan dari limbah detergen adalah dengan pengambilan kembali surfaktan dari larutannya [2]. 
Metode yang telah dikembangkan dalam pengambilan surfaktan adalah metode adsorbsi, metode ekstraksi pelarut, metode pertukaran ion dan metode kromatografi kolom. Penggunaan metode ekstraksi pelarut membutuhkan waktu yang relatif lama dan biaya yang cukup mahal, sedangkan dengan metode adsorbsi hasil yang didapatkan bukan merupakan surfaktan murni dan karena telah diadsorbsi maka kadang sulit dilakukan pengambilan dari adsorbennya. Penggunaan metode pertukaran ion lebih spesifik digunakan untuk pemisahan surfaktan jenis nonionik dari larutannya [3]. Berdasarkan kelemahan dari berbagai metode tersebut maka perlu alternatif penggunaan metode dalam pengambilan kembali surfaktan dari larutannya yaitu dengan menggunakan metode sublasi.

Metode sublasi memiliki keunggulan yaitu khusus digunakan untuk surfaktan. Adanya sifat hidrofob dan hidrofil menyebabkan surfaktan terkumpul pada antar muka cair dengan fase lainnya, sehingga dengan metode sublasi diharapkan surfaktan dapat teradsorbsi pada antar muka cair-gas dan surfaktan dapat dipisahkan dari larutannya. Metode ini diperkuat dengan hasil penelitian [4] yang telah berhasil melakukan sublasi surfaktan dari larutan surfaktan murni.

Pada penelitian sebelumnya [5] pengambilan surfaktan dari model limbah cair cucian dengan metode sublasi telah dilakukan. Hasil yang diperoleh yaitu surfaktan yang terambil dari model limbah cair cucian yang digunakan adalah sekitar $80 \%$. Namun, pada penelitian tersebut belum dilakukan uji detergensi untuk mengetahui daya detergensi surfaktan yang dihasilkan. Uji detergensi dilakukan dengan penambahan natrium tripolyfosfat, karboksimetil selulosa dan $\mathrm{NaOH}$ dengan penambahan buffer.

\section{Tinjauan Pustaka}

Metode Pemisahan Adsorbsi Gelembung (Sublasi)

Sublasi adalah sebuah proses yang digunakan untuk memindahkan surfaktan dari larutan dan menghasilkan senyawa padat yang selanjutnya dianalisa. Penggunaan sublasi sebagai metode pemisahan dikarenakan metode sublasi relatif sederhana, mampu mengisolasi semua jenis surfaktan dari fase cairnya dan didapatkan sisa sublasi yang relatif bebas dari bahan-bahan yang mengandung surfaktan [2].

Proses sublasi dilakukan dengan membuat gelembung-gelembung yang dilewatkan melalui tabung yang berisi larutan surfaktan etil asetat yang berada pada lapisan atas karena berat jenis yang lebih kecil daripada air dan sifatnya yang semipolar. Gelembunggelembung gas yang melewati sampel akan membawa surfaktan karena adanya adsorbsi surfaktan pada antarmuka gas-cair dan akan membawa surfaktan ke atas sampai akhirnya pecah pada fase etil asetat dan surfaktan larut pada fase tersebut. Pemisahan surfaktan dilakukan dengan cara penguapan etil asetat sehingga didapat surfaktan sebagai residu [2, 4].

\section{Detergensi}

Detergensi adalah sifat spesifik yang dimiliki oleh zat aktif permukaan untuk membersihkan suatu permukaan dari kotoran [6]. Tetapi zat aktif permukaan tidak dapat membersihkan kotoran dari permukaan dengan sempurna tanpa adanya zat-zat lain sebagai penunjang, sehingga detergensi diartikan lebih khusus sebagai sifat spesifik yang dimiliki oleh zat aktif permukaan yang memperbesar daya bersih dari suatu larutan pencuci.

Proses detergensi merupakan proses yang terjadi secara adsorbsi dimana pada proses itu kotoran harus dihilangkan dari substrat. Detergen dalam kerjanya dipengaruhi beberapa hal, yang terpenting adalah jenis kotoran yang akan dihilangkan dan air yang digunakan. Detergen, khususnya surfaktannya, memiliki kemampuan yang unik untuk mengangkat kotoran, baik yang larut dalam air maupun yang tak larut dalam air. Salah satu ujung dari molekul surfaktan (ekor) bersifat lebih suka minyak atau tidak suka air (hidrofobik) akibatnya bagian ini mempenetrasi kotoran yang berminyak. Ujung molekul surfaktan satunya (kepala) lebih suka air (hidrofilik), bagian inilah yang berperan mengendorkan kotoran dari kain dan mendispersikan kotoran, sehingga tidak kembali menempel ke kain. Akibatnya warna kain akan dapat dipertahankan.

Umumnya proses detergensi selalu meliputi dua hal yaitu:

\section{a. Proses pelepasan kotoran pada substrat}

Proses pelepasan kotoran pada detergensi dibedakan menjadi dua bagian, berdasarkan jenis kotoran yang melekat pada substrat yaitu pelepasan kotoran padat dan pelepasan kotoran cair yang keduanya mempunyai mekanisme yang berlainan. Untuk solid soil (kotoran padat) seperti pasir, tanah, dan lemak padat, proses terlepasnya kotoran dari substrat melalui proses pembasahan, sedangkan untuk liquid soil (kotoran cair) seperti minyak, mekanisme terlepasnya kotoran dari substrat melalui proses penggulungan.

b. Suspensi kotoran kedalam larutan pencuci dan mencegah pengendapan ulang kotoran pada substrat.

Proses detergensi dapat dianalisa dengan membandingkan berat kain bersih, berat kain kotor dan berat kain setelah pencucian dengan detergen. Kain bersih (awal) yang sudah diketahui beratnya dikotori dengan kotaran standar yang terdiri dari kaolin, $\mathrm{FeCl}_{3}$, bensin, lemak, karbon hitam dilarutkan dalam aseton, dikeringkan dan ditimbang. Kain kering ditimbang dan dicatat sebagai berat kain yang telah terkena kotoran. Persentase kotoran yang menempel dinyatakan dalam persamaan 1.

$\mathrm{PK}=\frac{\mathrm{BKK}-\mathrm{BBB}}{\mathrm{BBB}} \times 100 \%$

keterangan:

$\begin{array}{ll}\text { PK } & \text { : persen kotoran yang menempel } \\ \text { BKK } & \text { : berat kain kotor } \\ \text { BBB } & \text { : berat kain bersih (awal) }\end{array}$ 
Kain kotor dicuci dengan larutan detergen dengan waktu tertentu, dikeringkan dan ditimbang. Persen kehilangan kotoran dihitung dengan persamaan (2).

$\mathrm{PK}^{\prime}=\frac{\mathrm{BKK}^{-\mathrm{BBB}^{\prime}}}{\mathrm{BBB}^{\prime}} \times 100 \%$

keterangan:

PK' : persen berkurangnya kotoran

BKK : berat kain kotor

BBB' : berat kain bersih setelah pencucian

Kemudian dari data persentase berkurangnya kotoran dan persentase kotoran yang menempel dapat dihitung kemampuan larutan pencuci dalam membersihkan substrat yang disebut sebagai detergensi dan dinyatakan dalam persamaan (3).

Detergensi $=\frac{P K^{\prime}}{P K} \times 100 \%$

keterangan:

PK : persen kotoran yang menempel

PK' : persen berkurangnya kotoran

\section{Larutan pencuci}

Larutan pencuci merupakan suatu larutan yang mempunyai sifat membersihkan. Salah satunya adalah detergen. Detergen adalah pembersih sintetis yang terbuat dari bahan-bahan turunan minyak bumi. Kandungan dari larutan pencuci terdiri dari bahanbahan surfaktan, builder, filler dan aditif.

a. Surfaktan, merupakan komponen penyusun utama. Surfaktan adalah zat aktif permukaan yang mempunyai ujung hidrofil (suka air) dan hidrofob (suka lemak). Bahan aktif ini berfungsi menurunkan tegangan permukaan air sehingga dapat melepaskan kotoran yang menempel pada permukaan bahan.

b. Builder, berfungsi meningkatkan efisiensi pencuci dari surfaktan dengan cara menonaktifkan mineral penyebab kesadahan air.

Empat kategori builder:

$\checkmark \quad$ Fosfat : sodium tri poly phosphate (STPP)

$\checkmark \quad$ Acetate: nitril tri acetate (NTA), ethylene diamine tetra acetate (EDTA)

$\checkmark \quad$ Silicate : zeolite

$\checkmark \quad$ Citrate : citrate acid

c. Filler adalah bahan tambahan detergen yang tidak mempunyai kemampuan meningkatkan daya cuci, tetapi menambah kualitas. Contoh: sodium sulfat.

d. Aditif adalah suplemen atau tambahan untuk membuat produk lebih menarik. Misalnya: pewangi, pelarut, pemutih, pewarna, dsb. Bahan ini tidak berhubungan langsung dengan daya cuci. Aditif ditambahkan dengan maksud komersialisasi produk. Contoh: enzim, borax, sodium chloride, karboksimetil selulosa.

\section{Metode}

Penelitian dilakukan dalam tiga tahap. Tahap pertama adalah pembuatan limbah cair, tahap kedua sublasi limbah cucian, dan tahap ketiga adalah uji detergensi. Surfaktan yang dihasilkan dari proses sublasi dilakukan analisis gugus fungsi dengan spektrofotometer FTIR. Uji detergensi dilakukan dengan mencuci kain katun yang telah terkotori dengan surfaktan hasil sublasi ditambah dengan zat aditif natrium tripolyfosfat, $\mathrm{NaOH}$, pengaturan buffer dan karboksimetil selulosa.

\section{Alat dan Bahan}

Alat. Alat-alat gelas standard, neraca analitik, seperangkat alat sublasi, $\mathrm{pH}$ meter, serta spektrofotometer FTIR Shimadzu 8210PC.

Bahan. Model limbah cair cucian rumah tangga, Etil asetat, gas $\mathrm{N} 2, \mathrm{NaOH}$ kristal, $\mathrm{NaCl}$ kristal, $\mathrm{NaHCO}_{3}$ kristal, akuades, $\mathrm{NH} 4 \mathrm{OH}, \mathrm{NH}_{4} \mathrm{Cl}$ kristal, aseton, kaolin, $\mathrm{FeCl}_{3}$, karbon, bensin mobil, lemak sapi, karboksimetil selulosa dan natrium tripolyfosfat.

\section{Pembuatan model limbah cair surfaktan hasil cucian}

Pelarutan 30 gram detergen dalam 10 liter aquades. Pakaian seberat $1 \mathrm{~kg}$ direndam selama 15 menit. Pakaian dicuci dan air limbah ditampung. Diambil $10 \mathrm{~mL}$ kemudian diencerkan dengan aquades sampai 1 liter.

Proses Sublasi

Seperangkat alat sublasi disusun seperti pada gambar 1.

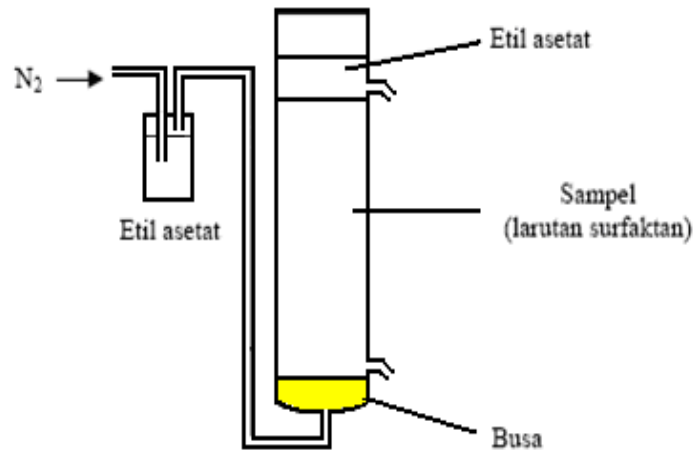

Gambar 1. Skema alat sublasi

Larutan surfaktan dialirkan secara perlahan ke dalam tabung sublator. Ditambah garam $\mathrm{NaCl}$ seberat 80 gram dan $\mathrm{NaHCO} 3$ seberat 4 gram. Sebanyak $50 \mathrm{~mL}$ etil asetat dialirkan secara perlahan melalui dinding tabung sublator hingga terbentuk lapisan di atas larutan surfaktan. Gas N2 dialirkan ke dalam larutan etil asetat yang berada pada tabung lain. Proses tersebut dilakukan pada tekanan optimum $\left(0.5 \mathrm{~N} / \mathrm{cm}^{2}\right)$. Dilakukan sublasi 3 kali, dengan waktu masing-masing 10 menit. Larutan etil asetat-surfaktan ditampung dan dikumpulkan. 


\section{Proses detergensi}

\section{Pembuatan Kotoran Standar}

Menimbang sebanyak 19,32 gram kaolin, 600 mgram feriklorida, 80 mgram karbon hitam, 5 gram bensin mobil, 10 gram lemak sapi. Masing- masing disuspensikan dengan aseton kedalam gelas piala 25 mL. Larutan kemudian dimasukkan kedalam gelas ukur $500 \mathrm{~mL}$ dan ditambahkan aseton hingga tanda batas. Labu ditutup dan dikocok selama 5 menit hingga benarbenar bercampur.

\section{Pembuatan Substrat}

Kain katun putih dipotong-potong dengan ukuran $10 \times 10 \mathrm{~cm}$, kemudian dikeringkan dalam oven dengan suhu pemanasan kira-kira $105^{\circ} \mathrm{C}$ selama \pm 3 jam hingga dicapai berat kain yang konstan. Kain katun dimasukkan dalam desikator \pm 1 jam. Kain kering kemudian ditimbang dan dicatat sebagai bobot bersih, yang kemudian kain ini disebut substrat.

Uji detergensi dilakukan dengan cara menyiapkan substrat yang telah dibuat. Substrat dimasukkan dalam gelas piala $1000 \mathrm{ml}$ yang berisi kotoran standar sambil diaduk-aduk selama 30 menit. Setelah kotoran menempel pada kain, kain diangkat dan dianginanginkan selama 30 menit. Setelah kain kering, kain dioven lagi selama 3 jam hingga diperoleh berat yang konstan dalam suhu $105^{\circ} \mathrm{C}$. Kain dimasukkan desikator selama 1 jam. Kain kering ditimbang dan dicatat sebagai berat kain yang telah terkena kotoran.

Kain yang telah terkena kotoran tersebut dioven lagi selama 1 jam. Kemudian kain dicuci dengan larutan pencuci surfakan hasil sublasi dengan penambahan buffer dan memvariasikan konsentrasi zat aditifnya selama kurang lebih 30 menit. Pada proses detergensi ditambahkan sodium tripolyphosphat $60 \%$ dan buffer $\mathrm{pH}$ 10. Variasi konsentrasi CMC yang dilakukan adalah 0 $\% ; 0,5 \% ; 1 \% ; 1,5 \% ; 2 \%$; dan $2,5 \%$;. Setelah proses pencucian, kain dibilas dengan air kran dan dianginanginkan selama kurang lebih 30 menit. Kemudian kain dioven selama 3 jam pada suhu 1050C, dan didesikator selama 1 jam. Kain yang telah bersih ditimbang dan dicatat berat bersihnya. Kemudian dari data persen berkurangnya kotoran dan persen kotoran yang menempel dapat dihitung persen detergensi dengan membandingkan persentasenya.

\section{Hasil dan Pembahasan}

\section{Sublasi Limbah Cair Cucian}

Proses sublasi dapat mengisolasi surfaktan dari fasa airnya sehingga diperoleh hasil yang relatif bebas dari bahan-bahan non surfaktan. Oleh karena itu, metode sublasi dapat digunakan sebagai salah satu cara untuk mengatasi masalah surfaktan di lingkungan dalam kehidupan sehari-hari. Dalam proses sublasi digunakan gas nitrogen dan etil asetat untuk mengadsorpsi surfaktan yang terdapat pada limbah cair cucian. Gelembung yang terjadi merupakan gelembung nitrogen-etil asetat yaitu dispersi gas nitrogen dalam etil asetat dan air, sehingga gaya Van der Waals gugus hidrofobik dari surfaktan akan teradsorpsi pada permukaan gelembung dan mengarah pada etil asetat. Laju alir gelembung gas pengadsorbsi adalah $0,5 \mathrm{~N} / \mathrm{m}^{2}$. Pada proses sublasi, digunakan spon (busa) sebagai bahan berpori kecil sehingga diharapkan gelembung yang terjadi akan berukuran kecil dan lebih banyak. Dengan waktu sublasi yang sama dan diameter tabung sublasi yang sama pula, surfaktan akan lebih banyak teradsorbsi pada gelembung kecil karena mempunyai luas permukaan yang lebih besar sehingga konsentrasi surfaktan yang terambil kembali pun akan lebih besar. Penambahan garam $\mathrm{NaCl}$ dan $\mathrm{NaHCO}_{3}$ dilakukan untuk mengurangi gaya tolakan antar ujung hidrofil. Pengurangan gaya tolak tersebut dikarenakan adanya distribusi ion-ion $\mathrm{Na}^{+}$sebagai hasil disosiasi garam yang menyebar pada ujung- ujung yang bermuatan negatif.

Analisis terhadap surfaktan hasil sublasi dilakukan dengan spektrofotometer FTIR. Metode analisis ini bertujuan untuk mengidentifikasi gugus fungsi yang terdapat pada surfaktan hasil sublasi. Spektra FTIR surfaktan hasil sublasi tercantum pada gambar 2 .

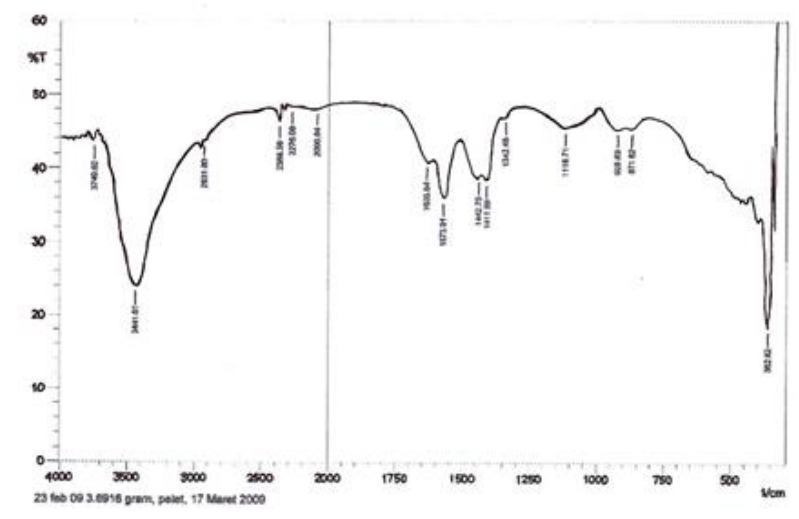

Gambar 2. Spektra FTIR surfaktan hasil sublasi

Dari data tersebut, serapan gugus fungsi surfaktan murni dapat dilihat pada tabel 1.

Tabel 1. Perbandingan surfaktan hasil sublasi dengan surfaktan murni

\begin{tabular}{|c|c|c|}
\hline $\begin{array}{c}\text { Gugus } \\
\text { fungsi }\end{array}$ & $\begin{array}{c}\text { surfaktan hasil sublasi } \\
\text { Frekuensi }\left(\mathrm{cm}^{-1}\right)\end{array}$ & $\begin{array}{c}\text { surfaktan murni } \\
\text { Frekuensi }\left(\mathrm{cm}^{-1}\right)\end{array}$ \\
\hline S=O & 1411.89 & 1377.1 \\
\hline OH & 3441.01 & 3421.5 \\
\hline Csp3-H & 2931.80 & 2923.9 \\
\hline $\begin{array}{c}\text { Csp2-H } \\
\text { aromatik }\end{array}$ & 1573.91 & 1569.9 \\
\hline
\end{tabular}

Berdasarkan hasil analisis di atas dan adanya kesesuaian dari spektra hasil sublasi dengan surfaktan LAS standar menunjukkan bahwa senyawa yang dihasilkan dari proses sublasi adalah surfaktan.

\section{Uji Detergensi}

Detergensi merupakan sifat spesifik dari zat aktif permukaan untuk membersihkan suatu permukaan dari 
kotoran [6]. Pada penelitian ini digunakan surfaktan hasil sublasi limbah cair cucian yang ditambahkan dengan karboksimetil selulosa (CMC) sebagai zat aditif pada berbagai konsentrasi. Karboksimetil selulosa merupakan bahan non aktif permukaan yang ditambahkan dalam suatu detergen yang berfungsi sebagai anti redeposisi atau mencegah menempelnya kembali kotoran pada substrat.

Mekanisme pelepasan kotoran cair pada substrat adalah dengan menggulung kotoran tersebut menjadi bulatan kotoran yang disuspensikan ke dalam larutan pencuci. Kecenderungan kotoran untuk membentuk suatu bulatan kotoran ditunjukkan oleh persamaan Young.

$\cos \theta=\frac{\gamma_{S L}-\gamma_{S O}}{\gamma_{L O}}$

$\gamma=$ tegangan permukaan

$\mathrm{L}=$ larutan pencuci

$\theta=$ sudut kontak antara larutan dan substrat

$\mathrm{S}=$ substrat

$\mathrm{O}=$ minyak

Pada uji detergensi ini, sodium tripolyphosphat (STPP) berfungsi untuk mengikat unsur-unsur penyebab kesadahan air yang menghalangi berlangsungnya proses pencucian. Natrium tripolifosfat mampu mengikat unsur $\mathrm{Mg}^{2+}$ dan $\mathrm{Ca}^{2+}$ sebagai penyebab kesadahan. Hal ini disebabkan karena $\mathrm{PO}_{4}^{3-}$ bebas memiliki kemampuan serangan terhadap senyawa $\mathrm{MgCO}_{3}$ dan $\mathrm{CaCO}_{3}$ membentuk ikatan yang lebih kuat dibanding ikatan dari kedua senyawa, serta menjadikan unsur-unsur penyebab kesadahan menjadi non aktif.

Pengaturan $\mathrm{pH}$ yang digunakan dilakukan pada $\mathrm{pH}$ 9-12 dengan variasi 0,5 . Pengaturan $\mathrm{pH}$ ini digunakan untuk menentukan $\mathrm{pH}$ optimum proses detergensi dan menentukan buffer yang akan digunakan pada proses selanjutnya. Pada proses detergensi $\mathrm{pH}$ larutan yang digunakan adalah $\mathrm{pH}$ basa karena adanya basa $\left(\mathrm{OH}^{-}\right)$ dari larutan maka akan menambah sumbangan muatan negatif pada kotoran-substrat sehingga dengan semakin kuatnya muatan negatif maka kotoran mudah terlepas dan proses detergensi dapat lebih optimal. Hasil yang diperoleh dari uji detergensi dengan penambahan STPP dan pengaturan pH dapat dilihat pada gambar 3 .

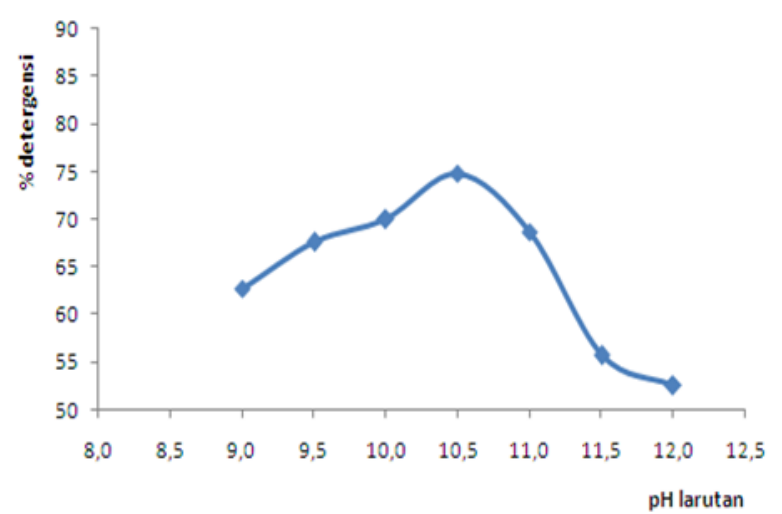

Dari grafik tersebut dapat dilihat bahwa detergensi maksimal terjadi pada $\mathrm{pH}$ 10,5. Selanjutnya dilakukan penambahan buffer yang sesuai untuk mengetahui pengaruh buffer tersebut. Larutan buffer digunakan untuk menjaga kestabilan pH. Larutan buffer terdiri dari asam lemah dan garamnya atau basa lemah dan garamnya. Pada proses detergensi $\mathrm{pH}$ larutan yang digunakan adalah $\mathrm{pH}$ 10,5 dengan buffer $\mathrm{pH}$ 10,5 antara $\mathrm{NH}_{4} \mathrm{OH}$ dan $\mathrm{NH}_{4} \mathrm{Cl}$. Hasil yang diperoleh dengan penambahan buffer akan meningkatkan detergensi surfaktan.

Senyawa karboksimetil selulosa (CMC) ditambahkan sebagai anti redeposisi atau mencegah menempelnya kembali kotoran pada substrat. Hasil yang diperoleh dari uji detergensi dengan penambahan STPP, pengaturan $\mathrm{pH}$, penambahan buffer dan CMC dapat dilihat pada gambar 4 .

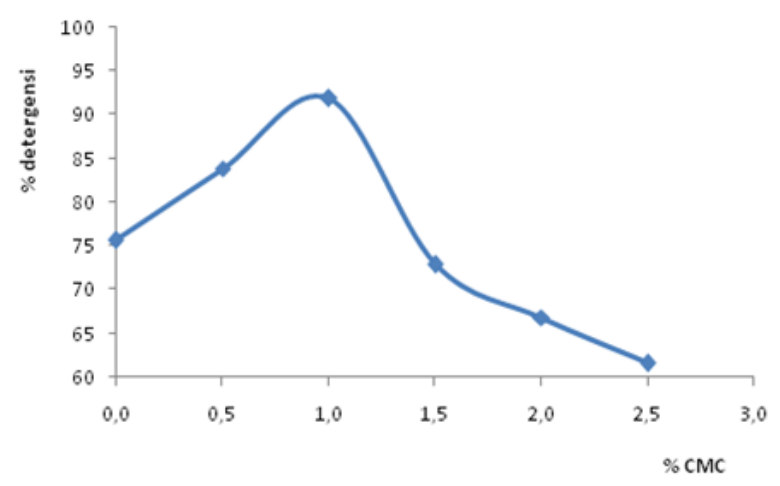

Gambar 4. Grafik hubungan+- detergensi dengan CMC

Dari grafik tersebut dapat diketahui bahwa pada pencucian tanpa CMC detergensinya rendah, tetapi setelah ditambahkan CMC maka akan meningkatkan detergensinya. Senyawa CMC akan mencegah menempelnya kembali kotoran pada substrat atau sebagai anti redeposisi. Pada grafik tersebut dapat dilihat bahwa penambahan CMC $1 \%$ memberikan nilai detergensi yang paling tinggi.

Uji detergensi pada penambahan CMC $0 \%$ dihasilkan detergensi rendah karena kotoran yang telah terangkat dapat menempel kembali pada substrat. Dengan adanya penambahan $\mathrm{CMC}$, kotoran yang telah terangkat tidak dapat kembali ke dalam substrat. Dalam larutan detergen, CMC akan menstabilkan emulsi yang terbentuk. Kotoran yang telah terangkat masuk ke dalam sistem yang stabil sehingga tidak akan kembali ke substrat. Senyawa CMC yang ditambahkan akan menaikan viskositas fasa kontinu sehingga sistem emulsi yang terbentuk menjadi lebih stabil. Tetapi pada penambahan CMC dalam jumlah yang lebih banyak akan menyebabkan detergensi turun. Hal ini disebabkan karena CMC merupakan suatu senyawa polimer organik polar, dalam jumlah besar senyawa ini tidak lagi menstabilkan emulsi yang ada tetapi sebaliknya akan mengganggu kestabilanya. Karboksimetil selulosa dapat menjadi kotoran dan masuk ke dalam substrat pada proses pencucian.

Gambar 3. Grafik hubungan detergensi dengan $\mathrm{pH}$ larutan 


\section{Kesimpulan}

1. Metode sublasi dapat digunakan untuk mengambil kembali surfaktan dari larutan encernya.

2. Penggunaan buffer $\mathrm{pH}$ pada proses pencucian dengan surfaktan hasil sublasi adalah 10,5 dan penambahan karboksimetil selulosa optimal pada konsentrasi $1 \%$.

3. Berdasarkan hasil penelitian diperoleh susunan larutan pencuci adalah: 23\% surfaktan, $60 \%$ STPP, pH 10.5, $1 \%$ CMC dan $\mathrm{Na}_{2} \mathrm{SO}_{4}$ sampai $100 \%$.

\section{Daftar Pustaka}

[1] Bakkarudin, Menjaga Lingkungan kita, Bandung 2008.

[2] S.L Clester, Standard Methods for the Examination of Water and Wastewater, American Public Health Association, New York, 1999.

[3] G. F. Longman, The analysis of detergents, Talanta, 22 (1975) 621-636.

[4] Febrina Zahara, Pengambilan kembali Surfaktan Alkil Benzena Sulfonat dari larutan encernya, in: Kimia, Universitas Diponegoro, Semarang, 1998.

[5] Ikhsanusin Bahri, Pengambilan kembali Surfaktan dari model limbah Cair cucian menggunakan metode sublasi, in, FMIPA UNDIP, 2005.

[6] Milton J Rosen, Joy T Kunjappu, Characteristic features of surfactants, Surfactants and Interfacial Phenomena, Fourth Edition, (1978) 1-38. 